Curran, principal of the Royal College of Science and Technology, Glasgow ; Prof. P. I. Dee, professor of natural philosophy, University of Glasgow; Prof. J. Diamond, professor of mechanical engineering, University of Manchester ; Mr. P. T. Fletcher, deputy managing director, Atomic Energy Authority, Developmont and Engineering Group, Risloy; Prof. J. E. Harris, professor of zoology, University of Bristol Mr. F. Hayday, member of the National Union of Gonoral and Municipal Workers and of the T.U.C. General Council ; Sir Willis Jackson, director of Rosearch and Education, Associated Eloctrical Industrics (Manchester), Ltd.; Major-General S. W. Joslin, H.M. chief inspector of nuclear installations ; Prof. J. M. Kay, professor of nuclear power, Imperial College of Science and Technology, University of London; Dr. John Loutit, director of the Medical Research Council Radiobiological Research Unit, Harwell ; Mr. T. W. McCullough, H.M. Chief Inspector of Factories; Dr. A. S. McLean, director, Health and Safety Branch, Atomic Energy Authority; Sir Georgo MeNaughton, lately chiof engineor, Ministry of Housing and Locel Government; Mr. R. E. Newell, managing director, Imperial Chemical Industries, Ltd., Wilton Works, Middlesbrough, Yorkshire; Mr. H. N. Pemborton, chief surveyor to Lloyd's Register ; Colonel G. W. Raby, managing director of Atomic Power Constructions, Ltd.; Mr. L. Rotherham, member for resoarch of the Central Electricity Generating Board; Sir William Slater, Agricultural Researeh Council; Dr. F. A. Vick, deputy director, Atomic Energy Research Establishment, Harwell

\section{Agricultural Pest Control and Wild-life}

The National Academy of Sciences-National Research Council has announced the formation of a Committee to investigate the relationship between chemical control of agricultural pests and conserve. tion of America's wild-life populations. The creation of the Committoe, which will function within tho Division of Biology and Agxiculture, is the most recent of several steps takon by the Academy-Research Council during the past few years in response to concern expressed in several quarters over use of chemicals to control agricultural pests. Tho members of the Cornmittoo are: Dr. Ira L. Baldwin, special assistant to the president of the University of Wisconsin (chairman) ; Dr. Ira N. Gabrielson, president of the Wildlife Managemont Institute; Dr. Tom H. Gill, exocutive director of the Charles Lathrop Pack Forestry Foundation; Dr. George L. MeNew, managing diroctor of the Boyce Thompson Institute ; Prof. E. C. Young, professor of economics and dean of the graduate school, Purdue University; and Dr. G. C. Decker, ontomologist, Illinois Natural History Survey. Dr. W. H. Larrimer, of the AcademyResearch Council, will serve as the oxecutive secretary of the Committec.

\section{The Royal Anthropo'ogical Institute: Awards}

THE following awards were made at the annual genoral meeting of the Royal Anthropological Institute of Great Britain and Iroland : The Huxley Memorial Medal for 1961, to Dr. A. E. Mourant, director of the Blood Group Reference Laboratory, Lister Institute; this Medal is the highest award that can bo mado to an anthropologist, and has been awarded annually by the Council of the Institute since 1900 ; The Rivers Memorial Medal, for anthropological fiold work, to Prof. J. C. Mitchell (University College of Salisbury, Southern Rhodesia); the
Wellcome Medal of the Institute for 1959, jointly to Mrs. E. M. Chilver, director of the Institute of Commonwealth Studies, Oxford, and Dr. P. Kaberry (University Colloge, London).

At the same meeting officers of the Institute for the session 1960-61 were elocted as follows : President, Dr. Audrey I. Richards; Vice-Presidents, Dr. (G. Caton Thompson, Prof. M. Fortes, Mr. I. M. Sieff; Honorary Secretary, Dr. Marian W. Smith ; Honorary Treasurer, Sir George Beresford-Stooke; and Honorary Editors, Mr. G. W. B. Huntingford and Mr. W. B. Fagg.

\section{Zebra: a New Zero Energy Reactor}

The United Kingdom Atomic Energy Authority has decided to build a zero energy fast reactor at the Atomic Enorgy Establishment, Winfrith. The reactor has been named Zebra (zero onorgy breeder reactor assembly). The reactor has been designed to permit the study of the neutron physics of $a$ wide variety of fuel assemblies containing uranium and plutonium. The assemblies under study will be built, up by loading fuel elements into a steel matrix (approximately a cube of side $10 \mathrm{ft}$.). The fuel elements contain both fuel plates and plates of neutron-absorbing material: the latter will be used to simulate the nuclear properties of the coolent and structure material which would be required in a power reactor. Zebra will be operated at room temperature and the heat output from the nuclear reactions in the core will be kept very low so that no cooling system is necossary. It is planned to commission the zero encrgy reactor during 1962. Zebra will be used to obtain information that will be needed for the design of a prototype which is likely to be the next step in the development of the fast reactor by the Authority. The work at Winfrith will complement that carriod out at the Dounreay Experimental Reactor Establishment.

\section{The Diploma in Mathematics}

THe Mathematical Association has now set up an Examinations Board to award a Diploma in Mathomatics (Dip. Maths.). The printed regulations are to be available in the early autumn of this year, and it is expected that the first examination will be hold at local centres in the British Isles in Novembor 1961. The Diploma is intended for teachers who have not had the opportunity of reading for a degree which includes mathematies. Considorablo interest in the proposal has been shown by the teacher-training colloges, the students of which might take the examination soon after comploting thoir three-year course if they havo taken mathematics as a special subject. Many of the technical colleges contemplate establishing part-time courses designed as a preparation for this Diploma.

A draft syllabus is now available from the Secretary of the Association at 29 Gordon Square, W.C.1. The examination will consist of four papers covoring three separate schomes of work, and candidates will be required to pass in all sections, though referonce on one occasion will be allowed in any one soction. The first two papers are in puro mathematics, and these will form the core of the Diploma. The standard expected is that which might bo reached by about a year of full-time study beyond the Advanced Level of the General Certificate of Education. The socond section deals with mechanies and statistics. In this part, bearing in mind tho special needs of women students, many of whom do none of this work at 